\title{
GLOBAL TRADE AND THE WORLD TRADE ORGANIZATION
}

\author{
Badar Alam Iqbal ${ }^{1}$ \\ Jorge Leandro Delconte Ferreira ${ }^{2}$
}

\begin{abstract}
Ailing global world is yet to recover from 2008's crisis. According to the World Trade Organization (WTO), global trade growth in terms of volume has recorded an increase of 2 per cent as compared to 5.2 per cent witnessed in 2011. The present paper analysis the emerging trends in global and Brazil's and India's foreign trade. The discussion reaches the question of a kind of confrontation between regionalism and multilateralism. The paper further outlines the emergence of new regionalism, which is a dangerous trend for multilateral trading system, and the role of WTO in accelerating the pace of world trade in years to come.
\end{abstract}

Keywords: World Trade.Brazilian Trade. Indian Trade. Multilateralism.

\section{COMÉRCIO INTERNACIONAL E A ORGANIZAÇÃO MUNDIAL DO COMÉRCIO}

RESUMO: Os níveis globais de comércio ainda não se recuperaram desde a crise de 2008. Segundo a Organização Mundial do Comércio (OMC), o crescimento do comércio mundial em termos de volume registrou um aumento de 2\%, em comparação com 5,2\% observados em 2011. $\mathrm{O}$ presente trabalho discute as tendências comerciais emergentes tanto em termos globais como nos casos específicos do Brasil e da Índia, em termos de comércio internacional. A discussão proposta aborda o ponto que parece constituir um dilema: o confronto entre regionalismo e multilateralismo. Este artigo salienta ainda a emergência de um novo regionalismo (que se constitui como tendência arriscada para o sistema multilateral de comércio) eo papel da OMC em acelerar o ritmo do comércio mundial nos próximos anos.

Palavras-chave: Comércio Mundial. Comércio Brasileiro. Comércio Indiano. Multilateralismo.

\footnotetext{
${ }^{1}$ Department of Commerce: Aligarh Muslim University. E-mail:bai_iqbal@mail.lycos.com. ${ }^{2}$ Professor assistente na Faculdade Estadual de Ciências e Letras de Campo Mourão - FECILCAM. E-mail: jorge.leandro.professor@gmail.com.
}

Recebido em 30/08/2013

Aceito em 09/10/2013 


\section{INTRODUCTION}

Global financial crisis and European sovereign debt crisis has affected global trade at large. The same is still not recovered. In the year 2011, global trade has registered a rise of 5.2 per cent in volume terms. While in the year 2012, the same has witnessed an increase of 2 per cent.

The World Trade Organization - WTO has also estimated the trade growth in volume terms for the year 2013 at 3.3 per cent, which is below the world's 20 year average growth of 5.3 per cent and also well below the pre-crisis period between 1999 and 2008 figure of 6 per cent. During this period, global exports registered a Compound Annual Growth Rate (CAGR) of 7 per cent. These trends testified that world trade is yet to recover from global economic crisis.

Following the global economic crisis, exports growth slowed down to 22.3 per cent in 2009, and thereafter recovered only in 2011. As important as the volume and value of exports is its location. The exporter countries can lead the world to a recovering way or can just work to benefit itself?

The major trading countries have shown the different trends in regard to exports and imports. Russian Federation, China and Brazil are the countries whose imports are less than exports having favorable balance of trade, whereas other major countries namely: United States, European Union, South Africa, Japan and India whose imports are much higher than exports having unfavorable balance of trade (Table 1). The highest favourable balance of trade has been in case of China, followed by Russian Federation and Brazil. The largest trade deficit has been in case of USA followed by EU, India, Japan and South Africa.

Table 1 - Trends in Trade Growth in Major Economies of the World in 2012 (US\$ Billion)

\begin{tabular}{|lrrr|}
\hline Country/Bloc & Exports & Imports & Balance of Trade \\
\hline China & $2.048,8$ & $1.818,1$ & $\mathbf{2 3 0 , 7}$ \\
\hline Russian Federation & 529,3 & 335,4 & $\mathbf{1 9 3 , 8}$ \\
\hline Brazil & 242,6 & 233,3 & $\mathbf{9 , 3}$ \\
\hline South Africa & 87,3 & 122,8 & $\mathbf{- 3 5 , 5}$ \\
\hline India & 293,2 & 489,4 & $\mathbf{- 1 9 6 , 2}$ \\
\hline European Union $(\mathbf{2 7})$ & $5.803,3$ & $6.305,9$ & $\mathbf{- 5 0 2 , 7}$ \\
\hline United States & $1.547,3$ & $2.335,4$ & $\mathbf{- 7 8 8 , 1}$ \\
\hline Japan & $\mathbf{7 9 8 , 6}$ & $\mathbf{8 8 5 , 8}$ & $\mathbf{- 8 7 , 3}$ \\
\hline
\end{tabular}

Source: Prepared by the authors from WTO (2013). 
In the year 2012, export growth presented different trends in major countries. When observing the performance of the emergent countries (the BRICS - Brazil, Russian Federation, India, China and South Africa) and some of the developed economies (Japan, USA, east Europe), we can see diverse signs of recovering or no recovering trade. In case of United States, Russian Federation and China, the balance of trade was positive, but with a quite significant variation. On the other hand, the performance of Brazil, European Union, South Africa, Japan and India it was negative (and in the case of South Africa, bigger than 10\%), as depicted in Chart 1.

Chart 1 - Exports Growth in Major Economies of the World in 2012

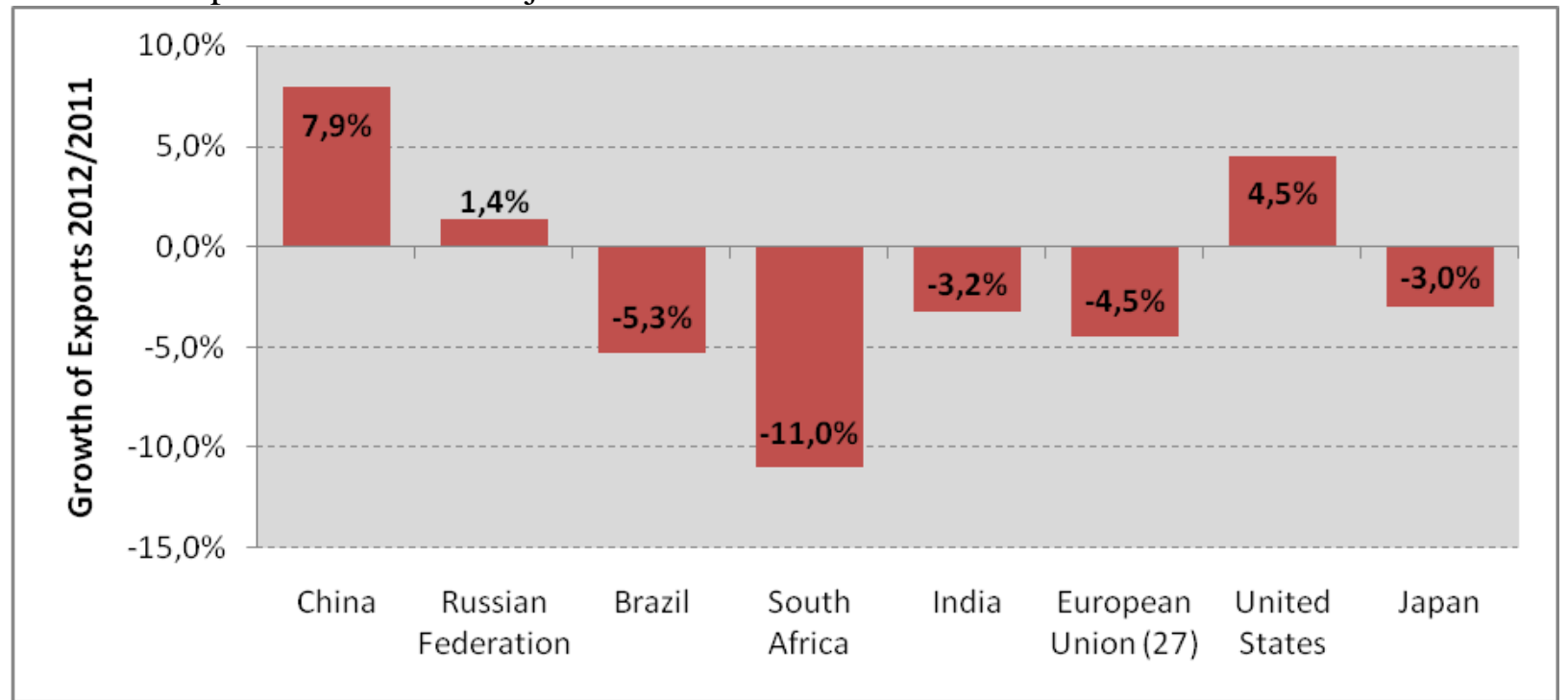

Source: Prepared by the authors from WTO (2013).

Nevertheless, on the other side, the average growth of exports during the period 20052012 has shown a different trend and as a result, all the major exporting countries have registered positive growth and highest average has been in case of India followed by China, Russian Federation and Brazil (Table 2). The other studied countries (including EU) shown an average growth lower than the average worldwide growth, which was 10.0 per cent during the period. The lowest average exports growth between 2005 and 2012 was concerningJapan i.e. just 5.6 per cent (Table 2). 
Table 2: Trends in Average Export Growth between 2005 and 2012

\begin{tabular}{|lc|}
\hline Country/Bloc & Average Export Growth $2005-2012$ \\
\hline India & $19.7 \%$ \\
\hline China & $\mathbf{1 7 . 8 \%}$ \\
\hline Russian Federation & $\mathbf{1 6 . 9 \%}$ \\
\hline Brazil & $\mathbf{1 3 . 7 \%}$ \\
\hline South Africa & $\mathbf{9 . 7 \%}$ \\
\hline United States & $\mathbf{9 . 0 \%}$ \\
\hline European Union $(\mathbf{2 7})$ & $\mathbf{6 . 4 \%}$ \\
\hline Japan & $\mathbf{5 . 6 \%}$ \\
\hline World & $\mathbf{1 0 . 0 \%}$ \\
\hline
\end{tabular}

Source: Prepared by the authors from WTO (2013).

Regarding to the Balance of Trade in the focused nations, the Chart 2 shows that all the countries had witnessing stability during the period of 2005and 2012. The exception was European Union, which had its lower balance in 2009, and 2012 been the second lower result. The United States had deficit in all the years of the period, and the other nations' turned around the equilibrium.

Chart 2: Balance of International Trade in Major Economies of the World in 2005-2012

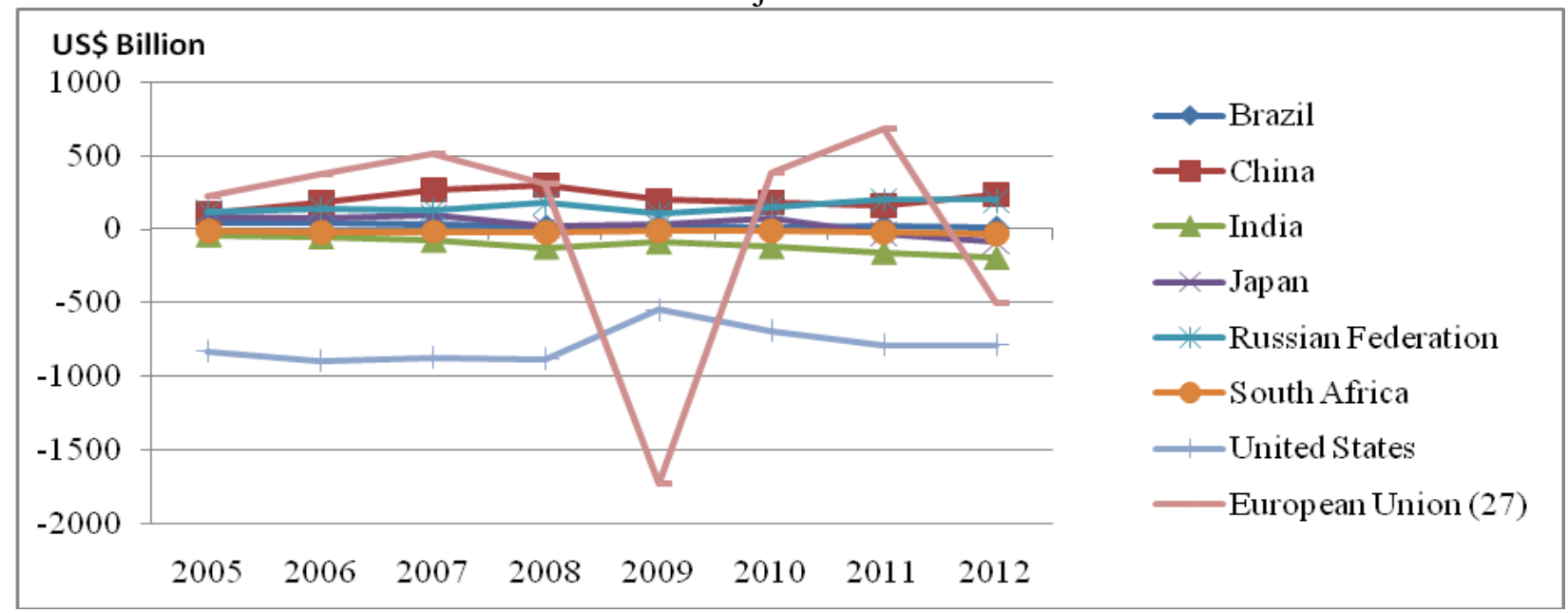

Source: Prepared by the authors from WTO (2013).

It is important to note that in 2009 U.S. and EU have opposite trends: while European countries saw in their trade balance a significant amount of decreases, the U.S. improved its trade balance significantly. 


\section{INDIA'S FOREIGN TRADE}

India's foreign trade scenario has also not been encouraging. Imports are rising faster than exports, resulting into rising trade deficit (Table 3). In the year 2009, India's exports amounted to US \$ 178.8 billion and imports were worth of US \$ 288.4 billion. Hence, trade balance was unfavorable amounting to US \$ 109.6 billion. However, in 2012, India’s exports were US \$ 300.6 billion and imports were US \$ 491.4 billion resulting into a trade deficit amounted to US \$ 190.8 billion almost the same as it was in the year 2009. This has been because of faster growth rate in exports than imports. There has been a continuous rise in the trade deficit. Nevertheless, in the current year i.e. 2013, India's exports grew for the fourth consecutive month recording a growth of $1.6 \%$ in April but surge in gold imports pushed the trade deficit to US \$ 17.7 billion. Gold and silver imports during April 2013were increased by 138 per cent to US \$ 7.5 billion (Chart 3).

Table 3: Trends in India's Foreign Trade between 2009 and 2012.

\begin{tabular}{|llll|}
\hline Year & Exports & Imports & Trade Deficit \\
\hline $\mathbf{2 0 0 9}$ & 178.9 & 288.4 & $\mathbf{1 0 9 . 6}$ \\
\hline $\mathbf{2 0 1 0}$ & 251.1 & 369.8 & $\mathbf{1 1 8 . 7}$ \\
\hline $\mathbf{2 0 1 1}$ & 489.3 & 306.0 & $\mathbf{1 8 3 . 3}$ \\
\hline $\mathbf{2 0 1 2}$ & $\mathbf{3 0 0 . 6}$ & $\mathbf{4 9 1 . 4}$ & $\mathbf{1 9 0 . 8}$ \\
\hline
\end{tabular}

Source: Prepared by the authors from INDIA, 2013. (US\$ Billion).

Imports of gold during April 2013 recorded a staggering growth of 138 per cent, threatening to further expand the current account deficit (CAD) and inflating the trade deficit to US \$17.8 billion.

According to the trade data released by Ministry of Commerce, gold imports amounted to US \$ 7.5 billion during April 2013 as against US \$ 3.1 billion in April 2012 despite several attempts by the Government of India to curb the gold import. Alarmed over substantial import of gold in 2011-12 amounted to US \$ 62 billion, the Government of India, in the last fiscal year, raised the basic customs duty on gold twice from 2 per cent to 4 per cent and then further to 6 per cent, expecting the import to decline. 
Chart 3: Monthly Trends in India's International Trade from April 2012 to April 2013.

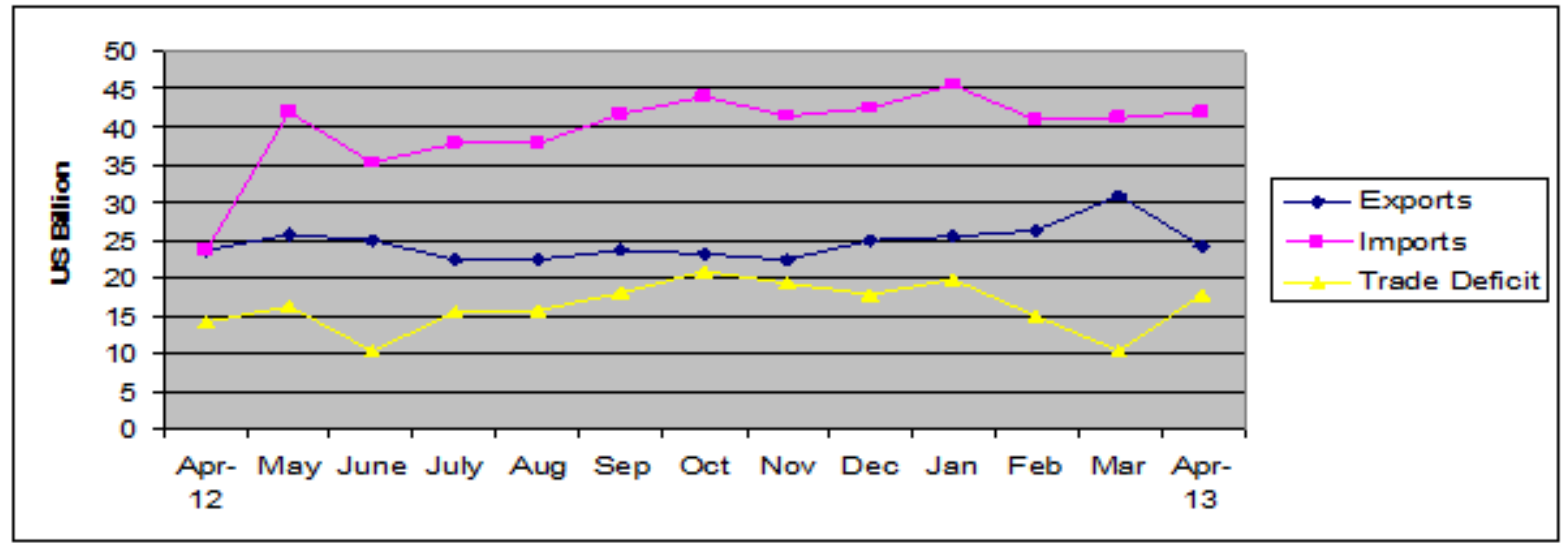

Source: Prepared by the authors from INDIA, 2013. (US\$ Billion).

The Prime Minister Economic Advisory Council (PMEAC) had expected it come down to a level of US $\$ 44$ billion in 2012-13. As a result of duty hikes import of gold decreased by 33 per cent in the first half, but the trend was reversed in the second half when import of gold increased by 24 per cent in the third quarter, and 11 per cent in the fourth quarter.

The items that recorded growth in the export basket comprises of gems and jewellery, rice, readymade garments, cotton and marine goods, while engineering goods, one of the major items, registered a decrease of 8.6 per cent. This decline could be attributed to the less competitiveness in the global market because of high cost of power. The export of readymade garments also registered an increase of 8.6 per cent. Textiles, have been recording negative growth. There is a positive growth of exports in the ready-made garments sector. According to (Sakthivel 2013), the RMG exports are now US \$ 1150 million compared to the last year, which was US \$ 1059 million.

Hit by world slowdown and especially in the traditional markets, India's exports fell to 1.6 per cent to US\$ 300.6 billion in 2012-13 while imports increased by 0.44 per cent to US \$ 491.48 billion, creating a huge trade deficit of US \$ 190.91 billion. Given the worsening balance of payment situation, Das (2013) affirms that India can make a case of for an outright ban on the import of gold.

Government of India sees this growing trade imbalances with concern and would be taking into stock this heavy import of gold and would come out with considered steps as how to contain this growth trade deficit (Rao, 2013).On the steps to discourage gold imports, Pujari 
(2013) points out that the Government had imposed certain increase in the duty but the steep fall in prices had neutralized its impact.

Besides, gold and silver, imports of crude oil, metals and scrap and chemicals witnessed an increase of 4 per cent, 52 per cent and 23 per cent respectively. After declining for consecutive eight months from May 2012, India's exports entered the positive zone in January 2013. The absence of alternative avenues of investment was also pushing demand for gold upwards. It is an inflation-proof investment for a citizen. If economic growth picks up, and better avenues fro investment appear, then the consumer behavior shifts (Business Express 2013).

Oil imports in April 2013 stood at US \$ 14 billion as compared to US \$ 13.5 billion in April 2012. Non-oil imports went up by a margin of nearly 15 per cent to US \$ 27.86 billion during the period under reference.

On exports growth, shipments were showing continuous positive up-tick. Sectors which recorded positive growth comprise of rice, gems, 22 per cent, ready-made garments 8.6 per cent, cotton 8.1 per cent, tea 5.4 per cent and marine goods 25 per cent. Sectors which witnessed negative growth include petroleum 0.5 per cent, engineering 8.6 per cent, chemicals 1.4 per cent, man-made yarn 3.3 per cent and pharmaceutical 1.6 per cent.

Positive growth trend are expected to continue in the coming times as new markets are performing better. The US market looking good. The economy is picking up but not so in Europe. Latin America, Africa and Far East nations continue to perform well. RBI's proposed measures to facilitate easy availability of credit to exporters, if accepted, would help in boosting exports further. India does see a positive curve out of dollar-dominated credit being available to exporters, according to (Hindu 2013). The Government of India has fixed a target of US \$ 325 billion for exports for the year 2013-14 which can be realized if the proposed measures are accepted by the Government.

\section{BRAZIL'S FOREIGN TRADE}

From April 2012 to April 2013, exports totaled U.S. \$ 239.400 billion. Compared with the previous twelve months, there was a decrease of $6.6 \%$, the daily average. On the other hand, imports totaled U.S. \$ 229.442 billion; an increase of $0.4 \%$ over the previous period, the daily 
Revista Economia e Desenvolvimento, v. 25, n. 2, 2013.

average. The accumulated trade balance totaled U.S. $\$ 9.958$ billion in the twelve months, $64.5 \%$ below the previous equivalent period.

Analyzing the period April 2012 to April 2013, four regions concentrate the advancement of Brazilian exports: Asia, Mercosur, the Middle East and Africa.

In the first quarter of 2013, exports of manufactured goods decreased $2.4 \%$ and the commodity fell even more, $3.7 \%$. With regard to manufactured goods increased by $1.2 \%$ over the same period last year (Table 3).

Table 3 - Brazilian Exports - Jan- April (by factor) - US \$ Million.

\begin{tabular}{|c|c|c|c|c|c|}
\hline & \multicolumn{2}{|c|}{ Jan-Apr } & \multirow{2}{*}{$\begin{array}{l}2013 / 2012(\%) \\
\text { Daily average. }\end{array}$} & \multicolumn{2}{|c|}{ Participation (\%) } \\
\hline & 2013 & 2012 & & 2013 & 2012 \\
\hline Commodities & 32950 & 34622 & $-3,7 \%$ & 46,1 & 46,4 \\
\hline Industrialized & 36.815 & 38.190 & $-2,4 \%$ & 51,5 & 51,2 \\
\hline manufactured & 9.809 & 9.811 & $1,2 \%$ & 13,7 & 13,1 \\
\hline Semi & 27.006 & 28.379 & $-3,7 \%$ & 37,8 & 38,0 \\
\hline Special opera. & 1.702 & 1.834 & $-6,1 \%$ & 2,4 & 2,5 \\
\hline TOTAL & 71.467 & 74.646 & $-3,1 \%$ & 100,0 & 100,0 \\
\hline
\end{tabular}

Source: MDIC, 2013.

The decline in the sales of commodities are mainly explained by the reduction of exports of crude oil ( $-54.3 \%$ to U.S. $\$ 3.5$ billion), rice grain ( $-44.9 \%$ to $\$ 125.2$ million) and coffee beans (-17.2\% to U.S. \$ 1.7 billion).The fall in exports of manufactured goods can be explained mainly by the decrease in exports of fuel oil ( $-40.2 \%$ to U.S. $\$ 1.1$ billion) and aircraft (-35.6\% to U.S. \$ 834.2 million). Semi-manufactured exports grew mainly copper cathodes $(+190.8 \%$ to U.S. \$ 173.7 million), raw sugar ( $+51.6 \%$ to U.S. \$ 2.6 billion) and leather ( $+18.7 \%$ to U.S. $\$ 758.1$ million).

In the first quarter of 2013 , exports decreased by $3.1 \%$, calculated on the daily average. Decreases occurred in major economic blocs, with the exception of the Middle East, Eastern Europe, Asia and Africa.

In particular, worries the decline in sales to the United States (second largest individual trading partner of Brazil), a decrease of $20.2 \%$, falling from $\$ 9.1$ billion in the first quarter of 2012 to $\$ 7.1$ billion in the same period of 2013 .

Exports to the European Union fell 9.3\%, from \$ 15.8 billion to $\$ 14.1$ billion (representing $19.8 \%$ of Brazilian exports). The main partners in the block are the Netherlands 
(U.S. \$ 4.4 billion, -8.6\%), Germany (U.S. \$ 2.0 billion, -17.6\%), United Kingdom (U.S. \$ 1.4 billion $+6.2 \%$ ), Italy (U.S. $\$ 1.3$ billion, $-16.0 \%$ ), Spain (U.S. $\$ 1.2$ billion, $-11.4 \%$ ), Belgium (U.S. \$ $\$ 1.2$ billion - 6.6\%) and France (U.S. \$ 1.2 billion, $-5.7 \%$ ).

Mercosur bought $\$ 8.7$ billion in Brazil, accounting for $12.2 \%$ of Brazilian sales. Argentina, the third largest individual partner of Brazil witnessed an increase by $8.2 \%$ to shopping, to $\$ 5.9$ billion in the first quarter of 2013 .

In Africa, exports grew $3.0 \%$ to $\$ 3.5$ billion (4.9\% of Brazilian exports). The major buyers were South Africa (U.S. \$ 604,700,000); Egypt (U.S. \$ 591,900,000); Angola (U.S. \$ 337.1 million) and Algeria (U.S. \$ 314.7 million).

There was also growth in sales (+3.8\%) for the Asian market, totaling U.S. \$ 22.2 billion in the first quarter. China, the largest individual trading partner of Brazil, bought $\$ 12.4$ billion (+ 5.9\%). Other prominent partners are Japan (U.S. \$ 2.7 billion, $+19.6 \%$ ), South Korea (U.S. \$ 1.6 billion, $+32.4 \%$ ) and India (U.S. $\$ 949.0$ million, $-50,7 \%$ ).

With these variations in performance of the Brazilian trade balance, it is observed that, although the balance accumulated in the past 12 months is positive for several months of the year was negative in the Brazilian commercial transactions, representing a risk of embitterment for emerging countries such as Brazil (Chart 4).

Chart 4: Monthly Trends in Brazil's International Trade from January 2012 to April 2013.

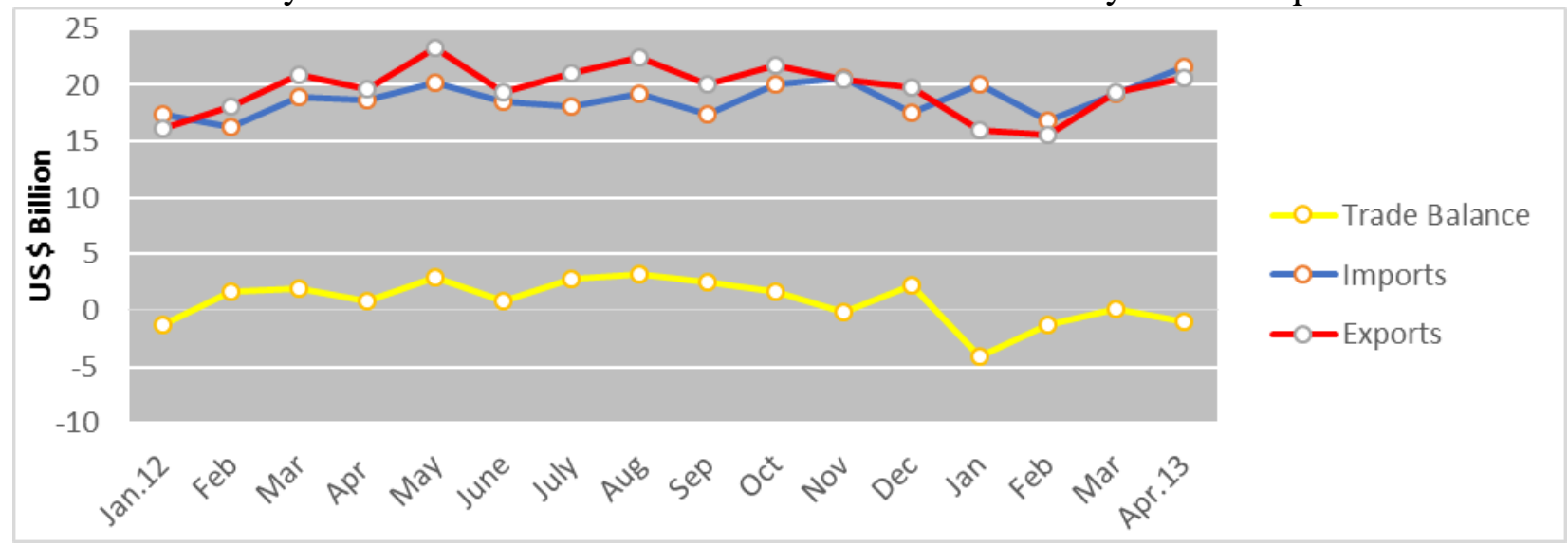

Source: Prepared by the authors from MDIC (2013).

It is clearly a trend different in the first quarter of 2013, compared to the same period last year. In this sense, the most critical month of the series was just January 2013. This worries not only because there was a reduction in exports this month, but also because imports grew sharply. 


\section{IS NEW REGIONALISM ON THE RISE?}

It is an undisputed fact that the multilateral framework for global trade has hardly made any significant breakthrough over the last five years. Since the month of September 2009, global trade negotiations were being considered as one of the most lukewarm phase. The global financial crisis and sovereign debt crisis in Europe have ensured that some of the global biggest players in world trade are delegated to playing a marginal role. This has had its effect on world trade, with the last five years producing an annual average growth of 2.2 per cent (PALIT, 2013).

The most distressing and unfortunate thing that has come up for the last five years is that world showing distinct signs of losing faith in the multilateral trading system which is sine-quonon for global trade. This is not only because of lack of progress on the Doha Development Round Agenda (DDRA). The result is that developing economies and emerging countries are unhappy over the DDRA not coming through in the WTO. On the other hand, the developed nations has realized that it is for them to push through their own trade agenda in the WTO and the DDRA is become virtually impossible get through. The unfortunate result that has come up is that the multilateral trading system is hereby facing the wrath of both the global North and South (INDIAN EXPRESS, 2013).

It is not correct to attribute the deadlock in the global trade negotiations and the crisis of the multilateral trading system to the world geopolitical order. The emergence of emerging market economies namely- China, India and Brazil and the weight these economies command has heavily influenced world trade negotiations. The main contributory factor is the lack of consensus on balancing benefits and contributions between newly emerging economies and the advanced OECD countries namely- the US, Europe and Japan resulting into prolonging the deadlock. There has been a gap between these groups in their respective perceptions about the global trade which is basically depending upon their different comparative advantages and the market access interests, has remained unbridgeable despite several round of global trade talks under the WTO regime.

The persisting disenchantment of the advanced nations with the existing multilateralism has resulted into a strong growth of regionalism. In fact regionalism had started reviving almost a decade back when a number of bilateral and regional trade agreements signed and notified by the WTO. China had tried to neutralize the damage to its exports by signing bilateral deals especially 
in Asia region. There are many Asian countries that were encouraged by regional agreements to facilitate their respective deep intra-industry trade trough similar rules of origin and standardization procedures. India and many other developing economies, majority belongs to Latin American and African continents, also became disillusioned with the WTO as the DDRA got deadlock and accordingly had tried for bilateral deals.

One of the strategic setbacks to the future prospects of multilateral trading system is realization by the member countries of the WTO the increasing drift of the USA. This was because the USA realized that emerging economies had become more strong and influential to let world trade be dominated by its own specific interests. The interests of the USA and other OECD economies are in making the "non-traditional or WTO-plus" trade issues more embedded in the existing multilateral framework. These comprises of rules on services, intellectual property, labor and environmental standards, Government procurement, e-Commerce and domestic regulatory coherence.

Many emerging market countries particularly BRICS, are feeling uncomfortable with the tabling of these issues in trade negotiations as these amount to making significant changes in internal regulations and stoking political sensitivities. Added to these, their respective comparative advantages in world trade are relatively low in industries where the "WTO-plus" issue are important namely- digital and entertainment goods. As a result, these are steadfastly opposed the demands of the USA and other OECD economies on these issues in the WTO (BARU,2013).

The most significant and the violation of WTO charter is that the USA is more focusing on bilateral agreements. The US Government has raised the voice/pitch through its commitment to the significant treaty known as Trans-pacific Partnership (TPP). This is comprised of many main economies of the Asia-Pacific namely- the USA, Australia, Brunei, Canada, Chile, Japan, Malaysia, Mexico, New Zealand, Peru, Singapore and Vietnam. The TPP is dealing with many 'WTO-Plus' issues and concentrating to attain regulatory convergence among members' countries.

It is widely believed that if above mentioned TPP is formalized in terms of regulatory convergence among members, it is likely to emerge one of the strong, sound and powerful regional agreements in the world having new trade rules. The most disturbing thing is that the advent of the TPP and the US commitment to the compact has been followed by the 
announcement of the Regional Comprehensive Economic Partnership (RCEP) in Asian region covering 10 members of ASEAN, Australia, China, India, Japan, New Zealand, and South Korea. Hence, formulization of RCEP will have far reaching implications, impact and consequences on the very spirit of WTO and its survival. Another dangerous trend which is also emerging out is that the USA is also seeking to formalize its bilateral trade linkages across the Atlanta by perusing a trade deal with the EU. This all means that when almost all major trading players are busy in scouting partners and trying to finalize the trade deals, the vision, mission and purpose of the multilateral trading system as a family with common rules appears to become irrelevant and the survival of WTO would be in doldrums.

\section{ROLE OF THE NEW DIRECTOR GENERAL}

It is rightly said and expected that geo-politics would define new WTO chief's candidature and geo-economics will shape his tenure. New Director General has to believe and realize that the globe is far more complicated than most people imagine it to be. Added to this, on the one hand the new geo-politics of the BRICS (Brazil, China, India, Russia and |South Africa) and on the other hand the old binaries of North-South and East-West defined the well succeeded candidature of the Brazilian Roberto Carvalho de Azevedo. It is also believed that the new DG agenda and his success will depend upon on his ability to mange and traverse the increasingly complex over lapping and intersecting economic interests and regional partnership which define the world economy today (AZEVEDO, 2013).

The most noteworthy fact is that whereas free trade purists have always rejected regional and plurilateral trading arrangements, the WTO's charter chose to be pragmatic and regarded Regional Trade Agreements (RTAs) and Free trade Agreements (FTAs) as building block of, rather than barriers to the multilateral trading system. The most astonishing thing is that India a strong advocate and strong defender of multilateral trading system, has been pursuing several RTAs and FTAs. During the last ten years.

It is evident now that the game plan of major trading players has changed. Due to persisting deadlock on Doha Development Round Agenda, the two biggest global trading players namely, the US and China are aggressively pursuing the formulization of Trans-pacific Partnership (TPP) as well as a Trans-Atlantic Trade and Investment Partnership (TTIP). These 
initiations/ measures are being amid at queering the pitch for the Doha Development Round. Bringing the issues that developing nations are resisting namely- labour, environmental standards and higher intellectual property rights protection into trade negotiations will create big rift among the members and may result into the collapse of DDRA in particular and WTO in general.

There are many contradictions in the viewpoint of emerging economies. For instance, China has started taking initiative to create its own plurilateral FTA in the grab of the Regional Comprehensive Economic Partnership (RCEP), which is against the Charter of WTO and the philosophy of Multilateral Trading System.

Brazil, on the other hand, hesitates to sign bilateral agreements of trade. It seems that Brazilian trade policy makers still believe that some kind of regionalism could reinforce itself after the crisis be won.

India, by its turn, has gone along with this so far, its interests, like those of the Latin American and African countries, which are not covered under TPP/TTIP/RCEP fold, would lie in strengthening multilateralism rather than succumbing to regionalism.

With the persistence of many challenges that WTO has been facing, the role of its new Director General must be to ensure the victory of multilateral trading system over newly emerging regionalism. He must develop a sound and strong strategy that must also appeal to G20 member countries. He has to play catalytic role and has to emerge himself consensus builder on the one hand and on the other to bring together the divided membership of the WTO.

\section{FINAL COMMENTS}

It is evident that global trade is ailing and the same is yet to recover. India and Brazil two major contributors to global trade are also witnessing the same trends. As there has been persisting deadlock in global trade negotiations, member countries are engaging in formulizing regional trade and free trade agreements. As result, the multilateral trading system is in doldrums and the survival of WTO is uncertain. Under these conditions, the role of new Director General is of paramount significance, very difficult and complicated. D.G. has to be a consensus builder as well as bridging the many divides in the global trading system. Its role is to show that WTO is more than useful, efficient and necessary for the globe and no one could conceive global trading system without WTO. 
Revista Economia e Desenvolvimento, v. 25, n. 2, 2013.

\section{REFERENCES}

AILING GLOBAL TRADE. The Indian Express, New Delhi, May 9, 2013. Business Express, p. $10-15$.

AZEVEDO, Roberto Carvalho.The Economics Times. The Indian Express, New Delhi, May 18, 2013. Business Express, p. 6-8.

BARU, Sundar. That man from Rio. The Indian Express, New Delhi, May 15, 2013. Business Express, p. 6-8.

CHENNAI. Exports up 1.6 per cent. The Hindu, New Delhi, May 13, 2013. Open Page, p. 9-11.

DAS,Abhijit. Heavy gold import widens trade deficit to $\$ 17.8$ bn. The Indian Express, New Delhi, May 14, 2013. Economic Bureau, p. 4-5.

INDIA - Ministry of Commerce and Industry. Trade Statistics. Available at:

<http://www.commerce.nic.in/ tradestats /indiatrade.asp?id=1>. Access: Aug. 2013.

INDIA'S Foreign Trade. The Indian Express, New Delhi, May 14, 2013. Business Express, p. $5-15$.

PALIT, Ahmed. The New Regionalism.The Indian Express, New Delhi, May 13, 2013.

Business Express, p. 10.

PUJARI, Anil. Annual Trade Report. Ministry of Commerce, Government of India. New Delhi, Dec. 2012.

RAO, Ramesh. Trade on the Rise: the word of Ministry of Commerce \& Industry. The Financial Express, New Delhi, January 12, 2013. Business Standard, p. 10-11.

SAKTHIVEL, Ajem. Role of APEC in Trade. The Financial Express, New Delhi, May 13, 2013. Business Standard, p. 12.

WTO - World Trade Organization. International Trade and Market Access Data. Available at: <http://www.wto.org/english/res_e/statis_e/statis_e.htm>. Access: aug. 2013. 